\title{
Reviewer Acknowledgements for Global Journal of Health Science, Vol. 10, No. 9
}

Global Journal of Health Science wishes to acknowledge the following individuals for their assistance with peer review of manuscripts for this issue. Their help and contributions in maintaining the quality of the journal are greatly appreciated.

Global Journal of Health Science is recruiting reviewers for the journal. If you are interested in becoming a reviewer, we welcome you to join us. Please find the application form and details at http://recruitment.ccsenet.org and e-mail the completed application form to gjhs@ccsenet.org.

\section{Reviewers for Volume 10, Number 9}

António Calha, Polytechnic Institute of Portalegre, Portugal

Arya Haj-Mirzaian, Johns Hopkins University, USA

Clauden Louis, University of Rochester Medical Center, United States

Dalia Salah El-Deen El-Sedawy, Cairo University, Egypt

David John Lindsay, James Cook University, Australia

David Otieno Odongo, Masinde Muliro University of Science and Technology, Kenya

Diadie Maiga, Management Sciences for Health in Arlington, United States of America

Domitila Augusta Huber, Federal University of Santa Catarina, Brazil

Emad Adel Shdaifat, Imam Abdulrahman Bin Faisal University, Saudi Arabia

Georgann Valerie Weissman, Capella University, United States

Jaime Hinzpeter, Clinical Hospital University of Chile, Chile

Joanne Cleary-Holdforth, Dublin City University, Ireland

Montarat Thavorncharoensap, Mahidol University, Ministry of Public Health, Thailand

Myo Nyein Aung, Juntendo University, Japan

Pi-Ming Yeh, Missouri Western State University, United States

Polly Yeung, Massey University, New Zealand

Robert Sloan, Kagoshima University Graduate School of Medical and Dental Sciences, Japan

Sara Melo, Queen's University Belfast, United Kingdom

Srikrishna Sulgodu Ramachandra, Public Health Foundation of India, India

Tan Ching Siang, Universiti Sciences Malaysia, Malaysia

Thomas Leiblein, Zurich University of Applied Sciences, Switzerland 